\title{
ОСОБЛИВОСТІ ВИВЧЕННЯ МАТЕМАТИЧНИХ ДИСЦИПЛІН МАЙБУТНІМИ ВЧИТЕЛЯМИ МАТЕМАТИКИ В УМОВАХ ЗМІШАНОГО НАВЧАННЯ
}

\author{
Чібісов О. Д.
}

кандидат фізико-математичних наук, доцент кафедри математики, Харківський національний педагогічний університет імені Г. С. Сковороди, м. Харків, Україна

\section{Простакова Ю. С.}

кандидат педагогічних наук, доцент кафедри математики, Харківський національний педагогічний університет імені Г. С. Сковороди, м. Харків, Україна

\section{Штонда О. Г.}

кандидат педагогічних наук, доцент кафедри математики, Харківський національний педагогічний університет імені Г. С. Сковороди, м. Харків, Україна

Авторами зазначено, щуо організовувати освітній процес майбутніх учителів математики в умовах змішаного навчання дочільно з використання онлайн-сервісів зі створення інтерактивних вправ, які дозволяють: індивідуалізувати освітній прочес відповідно до особливостей та потреб студентів; організувати навчальний матеріал з урахуванням різноманітних способів навчальної діяльності; посилити візуальне сприйняття та полегшити засвоєння навчального матеріалу; активізувати пізнавальну діяльність студентів.

Ключові слова: підготовка, вчителі математики, освітній процес, змімане навчання, педагогічний університет.

The authors noted that to organize the educational process of future teachers of mathematics in a blended environment, it is advisable to use online services to create interactive exercises that allow: individualize the educational process according to the characteristics and needs of students; to organize educational material taking into account various ways of educational activity; to strengthen the visual perception and facilitate the assimilation of educational material; to intensify the cognitive activity of students.

Key words: training, mathematics teachers, educational process, blended learning, pedagogical university. 
Серед засобів навчання математики інформаційні технології в умовах пандемії посіли важливе місце. Упровадження в освітній процес мультимедійних презентацій, тестових програм, електронних підручників, спеціалізованих програм для створення графіків функцій або геометричних об'єктів є складовою навчання математики. Застосування інтерактивних вправ, мобільних пристроїв, інтерактивних онлайндошок, сервісів для створення ментальних карт, мікроблогінгу, додатків на базі доповненої реальності дають змогу реалізувати інноваційні підходи до процесу навчання математики.

Проведений аналіз наукової літератури $[1 ; 2 ; 3]$ та власний досвід дозволив виділити основні засоби інформаційних технологій, які традиційно використовуються у процесі навчання математики.

До них віднесемо:

- мультимедійні презентації, які найчастіше супроводжують вивчення теоретичного матеріалу;

- електронні підручники із вбудованими відеофрагментами, тестовими запитаннями та запитаннями для самоконтролю;

- тестові середовища тощо [3, с. 5-6].

Нинішній стрімкий розвиток інформаційних технологій, зокрема i тих, які можуть з успіхом використовуватися в процесі навчання, значно оновлює зазначений перелік. Сучасні засоби інформаційних технологій дозволяють не тільки отримувати готову інформацію з різних джерел, а й проводити збір та аналіз інформації, щоб потім самостійно зробити висновки та отримати результати, що відповідає завданням, що стоять перед вчителями в умовах НУШ [1, с. 40].

Але поряд 3 актуальністю упровадження в освітній процес змішаного навчання зазначених засобів, виникають і такі труднощі:

- відсутність необхідного матеріального та технічного забезпечення: у школах не завжди є необхідний набір обладнання (переважно обладнані кабінети інформатики) або техніка, що використовується в процесі навчання, не дозволяє реалізувати наявні можливості інформаційних технологій;

- відсутність необхідної підготовки вчителів (особливо середнього та старшого віку) у галузі застосування сучасних інформаційних технологій;

- недостатня методична опрацьованість інноваційних підходів до використання інформаційних технологій, а самостійна підготовка та 
розробка навчальних матеріалів потребує дуже великої кількості часу, який вчитель найчастіше не має.

У зв'язку з цим виникає проблема, яка полягає у необхідності вивчення сучасних можливостей інформаційних технологій та розробки методичних рекомендацій щодо їх застосування у процесі навчання математики у школі, а також особливої уваги заслуговує сам процес підготовки майбутніх учителів математики в умовах змішаного навчання.

Слід зазначити, що різноманітні форми інтерактивних завдань дозволяють активізувати розумову діяльність здобувачів і утримувати їхню увагу на матеріалі, що вивчається.

Значне місце займають також мобільні пристрої та спеціальні програми до них [2, с. 105].

Мобільні пристрої (смартфони та планшети) після встановлення на них спеціальних програм можуть використовуватися як лінійки або транспортири. Утім, слід зазначити, що використання цих можливостей неприпустимо на етапі знайомства учнів 3 даними вимірювальними інструментами та формування початкових навичок виконання вимірювань на площині, але буде дуже корисним при розв'язанні задач практичного змісту з геометрії у 7-11 класах.

Спеціалізовані програми та програми, встановлені на мобільні пристрої, роблять їх справжніми помічниками при підготовці вчителя математики в умовах змішаного навчання.

Відзначимо найцікавіші можливості роботи з такими програмами:

- використання спеціалізованих калькуляторів (з їх допомогою можна організувати міні-дослідження для отримання висновків у процесі розв'язання завдань);

- програми-тренажери, які можна рекомендувати для використання здобувачами в позааудиторній діяльності з метою відпрацювання певних умінь та навичок;

- мобільні версії відомих програм роботи з математичними об'єктами (наприклад, GeoGebra), які дозволяють проводити обчислення, будувати графіки функцій чи геометричні креслення).

Отже, використання зазначених засобів інформаційних технологій значно активізують пізнавальні процеси при підготовці майбутніх учителів математики в умовах змішаного навчання, підвищує інтерес до вивчення математики. 
Особливістю багатьох розглянутих ресурсів $є$ їх універсальність до застосування у процесі навчання математичних дисциплін. Це дозволяє зробити висновок про доцільність використання всіх розглянутих сервісів та ресурсів у системі неперервної математичної освіти.

\section{Список використаних джерел:}

1. Жерновникова О.А., Коваленко О.А, Коваленко Л.М. Методи організації змішаного навчання в умовах університету. Психолого-педагогічні проблеми вищої і середньої освіти в умовах сучасних викликів: теорія і практика : матер. V Міжнар. наук.-практ. конф. (31 березня - 02 квітня 2021, м. Харків). Харків, 2021. С. 36-42.

2. Наливайко Н., Наливайко О. Змішане навчання в медичних закладах вищої освіти. Освітологічний дискурс. 2021. №32 (1). С. 101-111. DOI:https:// doi.org/10.28925/2312-5829.2021.1.7.

3. Ponomarova N., Gulich O., Zhernovnykova O., Olefirenko N., Masych N. Conditions of blended learning implementation in H. S. Skovoroda Kharkiv National Pedagogical University: experience of Physics and Mathematics Faculty. Second International Conference on History, Theory and Methodology of Learning (ICHTML 2021). Kryvyi Rih, Ukraine, May 12-14, 2021. P. 1-8. URL: https://doi.org/10.1051/shsconf/202110402017/ 